\section{Soviet rivers}

\section{Ambivalently flows the $\mathrm{Ob}$}

SibERIAN rivers, a favourite target of grandiose planning since the early days of Soviet rule, are no longer destined to "run backwards". Instead, a carefully calculated "part of the flow" will be channelled southwards, after possible "climatic and ecological changes" have been taken into consideration.

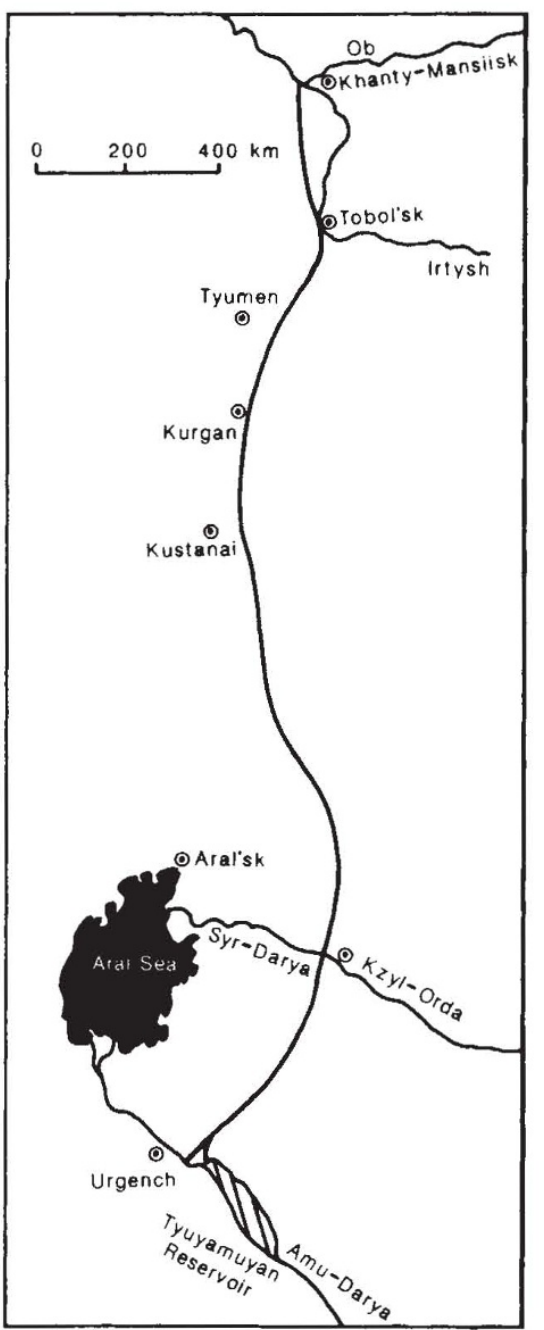

Massive hydroengineering projects, involving the imposition of the planners' will on nature, seem to appeal to the Soviets. In the $1920 \mathrm{~s}$, the need for such schemes was enthusiastically espoused by the propagandists of atheism on the grounds that, if God existed, He would have designed Siberia more rationally. In the 1930 s, the construction of the White Sea Canal absorbed thousands of the victims of Stalin's purges and could be explained, if necessary, abroad, as "reeducation through labour".

In the early 1970 s, the need to divert the Siberian rivers was used as an argument for peaceful nuclear explosions (an option since abandoned by treaty). But the international outcry in the 1970 s against the possible effect of such diversion schemes on the Arctic, and indirectly on the weather worldwide, evoked, first of all, Soviet assertions that all ecological factors had been taken into consideration by the planners, and then somewhat later the launching of a major research project into the ecological consequences

The inauguration of the long-term "Food Programme" in 1982 (the last major policy decision of the Brezhnev era) once again emphasized the need for a grandiose irrigation project in Siberia. (In fact, irrigation is needed not only for food crops but also for cash crops such as cotton, but Brezhnev's team emphasized the food aspect.) At the same time, the name "Sibaral" first came into common use.

A map of the proposed "Sibaral" canal was published only last August, in Pravda Vostoka (Eastern Trust), a paper not normally accessible in Moscow, let alone abroad. Even here, very few details were given. While the accompanying article spoke glowingly of the four great pumping stations needed to lift the water to the Tyumen' watershed, the map gives no indication of where these will be sited. It merely traces the proposed route of the canal at an undefined distance to the east of Tyumen', Kurgan and Kustanai, crossing the Syr-Darya somewhere to the west of Kzyl-Orda, and entering the AmuDarya below the Tyuyamuyan reservoir east of Urgench.

Even more significantly, the Pravda Vostoka article reveals for the first time that there has been a major disagreement over the route. Since irrigation plans for Central Asia and Kazakhstan indicate that by 1987 the waters of the Syr-Darya and by 1995 those of the Amu-Darya will be totally consumed, there is every need to press ahead with the Sibaral, and in October 1984 the Plenum of the Central Committee of the CPSU brought the completion date forward to 1987. The task involves 6,000 million $\mathrm{m}^{3}$ of earthwork and 15 million $\mathrm{m}^{3}$ of concrete construction, to produce a canal $2,600 \mathrm{~km}$ long. $250 \mathrm{~m}$ wide and up to $12 \mathrm{~m}$ deep, with a flow of water of up to $1,150 \mathrm{~m}^{3}$ per $\mathrm{s}$. Moreover, the project appears to have been held up by a dispute between the planners and the scientists. According to Pravda Vostoka, 23 institutes of the Soviet Academy of Sciences and around 130 other research and design institutes have been involved in planning the Sibaral. Under their pressure, the planners have moved the canal route an unspecified distance eastward of the original track, where, it is claimed, it will have "no negative effect" on traditional agricultural systems, nature reserves and ancient forests, and will preserve animal migration routes. As well as pleasing the ecologists, the eastern variant has the support of the economists - the terrain, according to Pravda Vostoka, has considerably reduced the estimated construction and utilization costs. Vera Rich
Biosafety regulations

US at odds with OECD

\section{Washington}

THE Commissioner of the Food and Drug Administration (FDA), Dr Frank Young. has been strongly criticized by two US congressmen for failing to resolve an inter-agency dispute that is putting in jeopardy an international study attempting to develop uniform approaches to biotechnology regulation. A completely rewritten draft of the study report, produced by FDA, ignores agreements reached previously with other member countries of the Organisation for Economic Cooperation and Development (OECD), according to Representative John Dingell and Senator David Durenberger.

The OECD report should have been completed in June this year, but at a meeting in May in Paris the United States completely reversed its earlier approach, leaving other delegates wondering whether it was trying to scuttle the project. The report had been two years in preparation, under the chairmanship of Dr Roger Nourish of the United Kingdom's Health and Safety Executive.

Until the May meeting, the US delegation had been led by the Environmental Protection Agency (EPA). But FDA's biotechnology policy coordinator, $\mathrm{Dr}$ Henry Miller, was put in charge of the delegation after voicing strong jbjections to the direction the studv $\mathrm{w}$, taking under EPA. Miller was actively opposed by EPA delegates in Paris, and the delegation "completely disintegrated", according to one observer.

The highly-charged quarrel between FDA and EPA mirrors an earlier dispute between FDA and the National Institutes of Health over guidelines for human gene therapy, which FDA lost. Young, and through him Miller, lost some political kudos when Margaret Heckler agreed to step down as Secretary of Health and Human Services, and FDA's hopes of leading biotechnology policy-making are now open to question.

The May draft of the OECD study, produced when EPA was still in charge of the US delegation, devotes much space to descriptions of standard levels of containment and lays much store on flexibility, but gives no indication of how knowledge about possible hazards should be used to decide on appropriate containment levels. It lists only information that should "ideally" be taken into account. Some reviewers criticize it for being prescriptive, although almost the only firm recommendation is that viable engineered organisms used in industry be kept in closed systems. Most agree that the study was seriously flawed; opinions vary over whether it was rescuable.

The new FDA-inspired September 
draft, called Safety considerations for commercial and environmental applications of organisms derived by recombinant $D N A$, is so different as to be unrecognizable. In general, it plays down risks, and declares that its aim is to present "the maximum number of approaches a country might choose" to deal with safety considerations. It observes that "it is widely accepted that the hazards associated with recombinant-DNA-containing microorganisms may be assessed in the same way as those associated with other organisms", and concludes that "there is no scientific justification for singling out rDNA work for a special regulatory regime above that which is already established" for traditional biotechnology such as brewing. Residual concerns about predictability of field trials of modified organisms have been expressed "primarily by ecologists who generally possess no direct experience with rDNA or related techniques" and represent a minority opinion.

Dingell and Durenberger have written to Secretary of State George Schulz to ask that he get the OECD study "back on track". Many OECD countries are keen to have international authority for their regulatory approaches as soon as possible, and the 4-month delay brought about by the US shift has caused considerable irritation. But unless the FDA September draft is accepted, further delays are in prospect.

Tim Beardsley

\section{US-China nuclear deal \\ Washington}

THE odds against congressional ratification of the nuclear technology pact between the United States and China became slightly greater last week, when Senator Alan Cranston, the Californian Democrat whip, threw in his lot with opponents of the scheme. Cranston believes that China is exporting nuclear technology to Brazil, Argentina, Iran, South Africa and Pakistan, the countries with the "most dangerous" nuclear programmes, despite China's pledge not to provide others with the means to develop nuclear weapons. He also asserts that Richard Kennedy, negotiator of the agreement, has deliberately withheld this information from Congress.

China acknowledges that it has peaceful nuclear cooperation agreements with Pakistan and Brazil, but denies a similar relationship with Iran. A statement from China's foreign ministry in response to Cranston's comments says that China's nuclear cooperation with any other country serves only peaceful purposes.

Cranston will help John Glenn (Democrat, Ohio) and others to draft legislation making China's acquisition of US nuclear technologies more difficult without firmer assurances on its non-proliferation policy. But Cranston admits that the chances of Congress rejecting the pact are still slim.

Maxine Clarke

US data protection

\section{Privacy bill progresses slowly}

Washington

MODERNIZATION of regulations on the privacy of electronic communications moved further forward last week, when representatives of the industries concerned endorsed the proposed legislation with only a few minor quibbles. The Electronic Communication Protection Act was introduced to both houses of Congress last month, and there will be a series of hearings during the next few months before the final version is drafted and voted on.

To coincide with last week's hearings, the Office of Technology Assessment (OTA) released a report, part of a study of the effects of new information technology on the federal government, which concludes that the technological revolution of the past 20 years has far outpaced laws to protect civil liberties. OTA's survey of 142 federal agencies shows that about 25 per cent of them use, or plan to use, electronic surveillance and that 25 per cent use computerized records.

The "wiretap" law of 1968 made telephone calls private, but the dramatic changes since then in communication electronic mail, cellular and cordless telephones, radio and video surveillance have no associated statutory protection. OTA's report spells out how information technology is affecting electronic communications, but does not grasp the nettle of the national security agencies' use of the technologies.

The new act would extend protection to virtually all electronic communications, eliminating the distinction between common and private carriers. It would also protect against unauthorized disclosure of third records, regulate the government's use of pen registers and tracking devices and create penalties for illegal access. But the difficulty is freely acknowledged of allowing for future development in an area that attracts the most daring entrepeneurs, and which is thus liable to explosive development.

Fred Weingarten, one of the authors of OTA's report, says nevertheless that the bill is an "important effort at addressing the potentially significant threat to the traditional privacy of communication". One of the quickest ways for an information service company to go out of business is to abuse the privacy rights of customers, says Michael Nugent of ADAPSO, the trade association for the US software and services industry. ADAPSO and the Telelocator Network of America, the national association of radio common carriers that produces cordless telephones and radio paging services, gave their support to the bill at last week's hearings.

Representative Robert Kastenmeier (Democrat, Wisconsin) and Senator Patrick Leahy (Democrat, Vermont), co-sponsors of the bill, hope to encourage the information technology market by assuring customers of protection as well as by providing comprehensive statutory protection from unauthorized surveillance. Until Congress passes some form of legislation, interim decisions have to be made in the courts, a time-consuming, expensive and unsatisfactory process.

It is to be hoped that the US law, when passed, will avoid the vagueness that has caused so much controversy over Britain's Data Protection Act, which has been widely criticized for the scope it provides for invasion of civil liberties (see Nature 307, 494; 1984).

Maxine Clarke

\section{Texas technology}

\section{Washington}

Texas, the Lone Star state which was briefly last century an independent republic, is once again displaying secessional tendencies, this time in the more limited domain of scientific research. The state legislature has recently awarded 87 grants worth $\$ 35$ million to Texan colleges and universities for scientific and hightechnology research likely to bring economic benefits to the state.

The Texas Advanced Technology Research Program was the initiative of state lieutenant governor William Hobby. Its approval was all the more surprising because Texas this year faced a budget crisis due to falling oil revenues, and some unheard of (for Texas) austerity measures were introduced. Supporters of the scheme argued, however, that falling revenues were all the more reason to support research of the kind likely to generate "practical sorts of things" for the state.

Support was provided for seven principal areas of research: aerospace, agriculture, biotechnology, chemistry and physics, energy, microelectronics and telecommunications, and materials science. Decisions on which applications to support were made by a panel of experts appointed from outside the state, headed by Dr Frederick Seitz, who among other things chairs the advisory committee to the Strategic Defense Initiative. When Seitz asked whether applied or basic research should be favoured, he was told just to choose "the best", according to a state official. The University of Texas and Texas A\&M University were the main beneficiaries.

Texas claims its scheme is unique in the country. The initial $\$ 35$ million is for two years, but the scheme will be continued if all goes well. It has, according to the Texas official, received the blessing of the National Academy of Sciences, whose chairman, Dr Frank Press, is said to regard it as a prototype of what might be achieved elsewhere.

Tim Beardsley 